\title{
The Challenge of Decentralization in Indonesia: Symmetrical and Asymmetrical Debate
}

\author{
Indra Kesuma Nasution
}

\begin{abstract}
Based on Local autonomy law no. 32/2004, Indonesia has two models decentralization, namely symmetric and asymmetric decentralization. After the 1998 reform, many districts want asymmetric decentralization. Based on symmetrical decentralization experience in the New Order era did not have a positive impact on the region and community. Asymmetric decentralization is considered to be the solution for any such distinction exists in the geographic region, financial, natural resources, etc. But, in fact, asymmetric decentralization raises many problems. Therefore, This study aims to explain some of the issues arising from the implementation of symmetric and asymmetric decentralization based on the experience of Papua and Nusa Tenggara Barat. This paper finds that symmetrical and asymmetrical decentralization is not enough to be a solution for local and community improvement.
\end{abstract}

Index Terms-Symmetrical decentralization, asymmetrical decentralization, budget transfer, and poverty.

\section{INTRODUCTION}

Decentralization in Indonesia is not a new issue, and even decentralization has been around since the independence of Indonesia. New Order led by Suharto has produced an authoritarian regime [1]. Soeharto's regime did not solve the problem transparently and did not accommodate the many demands and claims that arose in areas such as Aceh, Riau, Irian Jaya and East Timor. Soeharto's authoritarian regime was creating demonstrations and people protests to bring down the New Order regime. The fall of the Soeharto's regime led to a new system called reformation. The implementation of decentralization in reform era gave authority for the local governments to govern many areas except monetary, religion, justice, security and defense, and international relations. Decentralization as a form of government policy, in essences, intended to bring the government to provide services to the society as a whole. Thus, the provided services tend to be more equitable and in accordance with the needs of the society in the area concerned. Decentralization attempted to be closer to the goals of governance to realize the ideals of a more just and prosperous society. Indonesia has two models of decentralization, symmetrical and asymmetrical decentralization. Symmetrical decentralization based on the assumption that all provinces have the same condition.

Asymmetrical decentralization based on characterized by the region or Special autonomy (otonomi khusus). However, the implementation of decentralization in Indonesia has many

Manuscript received May 22, 2015; revised July 22, 2015.

Indra Kesuma Nasution is with the Graduate School of International Development, Nagoya University, Japan (e-mail: indrathedream@yahoo.com). obstacles for examples conflict of region-province-state, budget conflict, conflicts of local revenue (PAD) and asset management. I argue that the problem caused by decentralization over the fundamental issue was related to the social model of social compliance and state power. David Held explained that social respect and state power was needed to create stability in the state. David Held argued that compliance results from a complex of interdependencies between people, collectivities, and institutions interdependencies that incorporate relations of power and dependence [2]. Based on the various arising problems in the implementation of decentralization, I argue that the core problem of the implementation of decentralization in Indonesia is began with a wrong decentralization model, which is not in accordance with the actual conditions in Indonesia. It can be proved that today, the Government of Indonesia does not have a grand design or a clear blueprint of the concept of decentralization.

A more effective decentralization model is needed to reduce the gaps and contradictions in the implementation of the decentralization of development. Actually, Development plan run into difficulties both at the planning and implementation stages. Implementation concerned has shown that the government has almost no delivery mechanism at the local level. The government cannot reach a large number or rural level, given existing managerial and financial constraint [3]. The decentralization should always be followed by setting up the harmonization of relations among the central government with the local government. Although there is no hierarchy in decentralization among districts with the province, but in terms of coordination, monitoring, control, and supervision, the province still had the authority to districts / municipalities. Base on that background, this research is as an effort to create a new model of decentralization and a study of decentralization which is more understanding about local government and more responsible for the better region.

\section{DeCEntralization CONCEPT}

Devas asserts that 'the term of decentralization, different things to different people and different approach [4]. The definition of decentralization in general refers to the definition Rondinelli and the World Bank. Rondinelli stated that decentralization as The transfer or delegation of legal and authority to plan, make decisions and manage public functions from the central governmental its agencies to field organizations of those agencies, subordinate units of government, semi autonomous public corporation, area wide or regional development authorities; functional authorities, autonomous local government, or non-governmental 
organizational [5]." World Bank explained that decentralization is a process of transferring responsibility, authority, and accountability for specific or broad management functions to lower levels within an organization, system or program [6]. In this case, decentralization is defined as the process of transfer of responsibility, authority and accountability of the management functions specifically or broadly to aim lower in an organization, system or program.

Litvack and Seldon explained that decentralization is transfer of authority and responsibility for public function from central to sub ordinate or quasi-independent government organization or the private sector [7]. In the same word, Crook argued that decentralization is usually referred to as the transfer of powers from central government to lower levels in a political-administrative and territorial hierarchy. In contrast, political, or democratic, decentralization refers to the transfer of authority to representative and downwardly accountable actors, such as elected local governments. Turner and Hulme explained that a transfer of authority to perform some service to the public from an individual or an agency in central government to some other individual or agency, which is 'closer' to the public to be served [8]. Paul Smoke explained that decentralization would improve the efficient provision of services, the quality of governance, economic development and efforts to alleviate poverty [9]. In other words, decentralization is a form of model of devolution of authority between the central and local governments. The formal structure of the decentralized system is likely to have an impact on a number of factors important to performance, such as administrative and technical capacities, cost, the degree to which accountability and legitimacy can be established, resources, managerial and budgetary autonomy and even the implementation of the reform itself [10]. Local autonomy in the name of democracy in the implementation of local politics in areas where the terrain has the right to determine policy decisions for the benefit of the region. Redford argued the enemy of democracy is not the power of the occupants of the strategic positions in the administrative state but the concentration of power in an elite, which integrates the administrative/political structure with a small leadership structure external to it. And the roles of administrators are significant only as an agency function for elite [11]. It was also explained by John Mary Kauzya that decentralization was a policy of high priority and used as an instrument of people empowerment, a platform for sustainable democratization [12].

\section{A. Symmetrical Decentralization}

We will start this discussion by defining symmetrical decentralization. Julius Mbeya explained that symmetrical decentralization is all the lower level units in the state are allocated equal autonomy in conducting the various roles and functions that have been decentralized without regard to the physical, ethnic, cultural [13]. It means that symmetrical decentralization based on the assumption that all provinces have the same condition. This assumption is taken by the central government for facilitating the regulatory system and political pressure [14].

\section{B. Asymmetrical Decentralization}

Charles Tarlton (1965) was the first scholar who started discussing on asymmetric decentralization. Charles insisted that the distinction between symmetric and asymmetric decentralization lied in the level of conformity and commonality in relation to a level of government with the political system, with the central government and between states. Asymmetrical decentralization pattern is charLawerized by "the level of conformity and commonality in the political relations of each separate unit of the system to both the system as a whole and to the other component units [15].

\section{Sequential Decentralization}

One of decentralization model is the sequential theory of decentralization proposed by Tulia Falleti. Falleti rejected the notion that decentralization automatically gives enormous power to the regional governments. All depends on the transfer of power. There are three types of power transferred sequentially (not once given), namely: administrative decentralization, fiscal decentralization and political decentralization [16]. Falleti explained if political decentralization takes place first, it enhances the bargaining power of subnational actors in subsequent rounds of negotiations over other types of decentralization. In this case, fiscal decentralization is likely to follow, with administrative decentralization occurring last. This sequence of reforms leads to a higher degree of autonomy for governors and mayors. So that, if administrative decentralization takes place first and is followed by fiscal decentralization and then political decentralization, this sequence of reforms enhances the power of the national executive and sets serious fiscal constraints on subnational executives.

\section{Sequential Asymmetric Decentralization}

Based on David Held theory, the fundamental problem in the state is how to build a good model or system that regulates social relations and the state to create stability in the state. Therefore, I offer the concept of the sequential asymmetric decentralization. Addressing to the number of the references, the choice of sequential asymmetrical decentralized development model based on the diversity of the region [17]. Each area is treated differently because it assumes the existence of extreme pluralism that the central government must respond. Basic idea of sequential asymmetric decentralization began in Indonesia under which decentralization should start from asymmetric. Every region in Indonesia has the diversity and capabilities that cannot be equated. However, the central government assumed that all provinces in Indonesia have the ability, the same circumstances. Based on government regulations (Peraturan Pemerintah) No. 38/2007 explained that provinces submitted 31 types of affairs in the same amount and the same authority as well [18]. I propose sequential asymmetric decentralization model to improve the decentralization in Indonesia. I argue that there must be a ranking system applied in decentralization. Then, periodically or once in five years, all the regions are evaluated by the central government to assess the results of the implementation of decentralization. 


\section{ASYMMETRICAL DECENTRALIZATION IN PAPUA}

Discourse about Papua is inseparable from the long history of Papua, which is full of conflicts. Institute of Indonesia Science (LIPI) teams explained that there are four significant matter about Papua in which are first, the integration process of Papua territory into the Republic of Indonesia is considered rife with incomplete problems. Hence, it was in 1964 emerged the Papua Independence Movement. Papuan either through armed resistance or political strength carried out these movements. The Indonesian government responded the demands by sending thousands of soldiers to curb and to oversee separatist movements. President Soeharto, as president at that moment, assigned Papua as the area of military operations. Second, during the status of a military operations area, it was occurred violence against Papuan by TNI (Indonesian national army). This violence leads to human rights abuses. Third, due to prolonged conflict, it significantly affects the economic and political development of being late. The side of education and health to be forgotten which was significantly impacted the failure of development in Papua [19].

\section{A. Budget and Social Impact: US\$2,8 Billion without Development}

Special autonomy in Papua was the beginning of attitude change of central government in carrying out development in Papua. The improvement of Papuan's welfare realized through the provision of an enormous budget of special autonomy. The Papua province got new budget sources other from the central government than local revenue. These budgets were ranging from 1 trillion (US $\$ 100$ million) to 3 trillion rupiahs (US\$ 300 million) in 2011. In 2009, this special autonomy budget experienced reduction over the previous year. So far, the government has granted the special autonomy budget by 28 trillion rupiahs (US $\$ 2,8$ billion) to Papua government. The next question is how the real condition of local revenue of Papua. It is essential to compare the local revenue of Papua with budget transferred from the central government. It is very important to know how dependent of Papua to budget transfer from the central government. The local revenue of Papua from 2002 to 2011 amounted to 2 trillion rupiahs (US\$ 200 million). Meanwhile, the total budget was transferred from the central government as much as 28 trillion rupiahs (US\$ 2,8 billion). It was clear that the local revenue of Papua depends on central government budget (Ministry of Finance Republic Indonesia). The next question is how the real condition of local revenue of Papua. It is essential to compare the local revenue of Papua with budget transferred from the central government. It is crucial to know how dependent of Papua to budget transfer from the central government.

The Table II explained that the local revenue of Papua from 2002 to 2011 amounted to 2 trillion rupiahs (US\$ 200 million). Meanwhile, the total budget was transferred from the central government as much as 28 trillion rupiahs (US\$ 2,8 billion). It was clear that the local revenue of Papua depends on the central government budget. Based on the total budget, it was supposed to the development enhancement in Papua. But, in fact, shows that the enormous budget of special autonomy has no positive impact on improving the quality of life of the Papuan. It proved by the increase in poverty in Papua. The implementation of special autonomy since 2001 was failed to reduce the number of poverty.

\begin{tabular}{ccr}
\multicolumn{2}{c}{ TABLE II: THE COMPARISON BETWEEN LOCAL REVENUE AND BUDGET } \\
TRANSFER FROM CENTRAL GOVERNMENT
\end{tabular}

TABLE III: SPECIAL AUTONOMY Budget AND PoOR PEOPLE

\begin{tabular}{crr}
\hline Year & Special Autonomy Budget & Poor People \\
\hline 2002 & $1,038,000,000,000.00$ & $41.80 \%$ \\
2003 & $1,539,560,000,000.00$ & $39.03 \%$ \\
2004 & $1,642,617,943,000.00$ & $38.69 \%$ \\
2005 & $2,775,312,000,000.00$ & $40.83 \%$ \\
2006 & $3,913,218,000,000.00$ & $40.40 \%$ \\
2007 & $3,274,230,000,000.00$ & $40.78 \%$ \\
2008 & $3,590,100,000,000.00$ & $45.96 \%$ \\
\hline 2009 & $2,609,796,089,000.00$ & $46.81 \%$ \\
\hline
\end{tabular}

The data explained that there is no significant poverty reduction in Papua. Enhancement percentage of special autonomy budgets is about $6 \%$ to $64 \%$ in 2006. Then, the decline in poverty stands at only $0.1 \%$ to $7.6 \%$ in 2008 . Special autonomy budgets experienced the highest increase in 2006 that $64 \%$ are only able to reduce the poverty rate by $0.43 \%$. It means the influence of special autonomy budgets towards poverty reduction in Papua is measly (see Table III).

\section{B. Authority Factor: Lack of Coordination}

In terms of authority, there is confusion between the authority of provincial government, Provincial House of Representatives, and the Papuan People's Assembly. Though, the three institutions each normatively has had regulatory framework regarding the position, duties, and functions. But in reality, it has not formed a functional relationship/coordination to define work areas and responsibilities of each. Ideally, the authority relations of the three institutions have been regulated by special local regulations. Lack of coordination in the relationship between these three institutions may block some political process, for example, local regulations for the election of governor.

The figure explained that the authority relations between the Provincial Government and the Government of District/Municipality also does not have a standard provision, because according to the meaning of Autonomy should it be regulated separately. The gap relations between the two institutions level because different law perspective. The provincial governments based on the Special Autonomy Law and the District/Municipality governments based on the local government Law (Law No. 32 of 2004). The impact of 
unclear of authority is a lack of coordination. This weakness is not only resulted in overlapping activities but also wastage of outstanding resources, which would immediately drain capability in providing welfare for the people of Papua. One of the problems in the implementation of special autonomy in Papua is the overlapping regulation associated with autonomy in Papua. As an implication, the level of practical implementation of special autonomy in Papua is also a clash of authority between levels of government. This collision resulted in the seizure of authority as well as throwing authority (see Fig. 1).

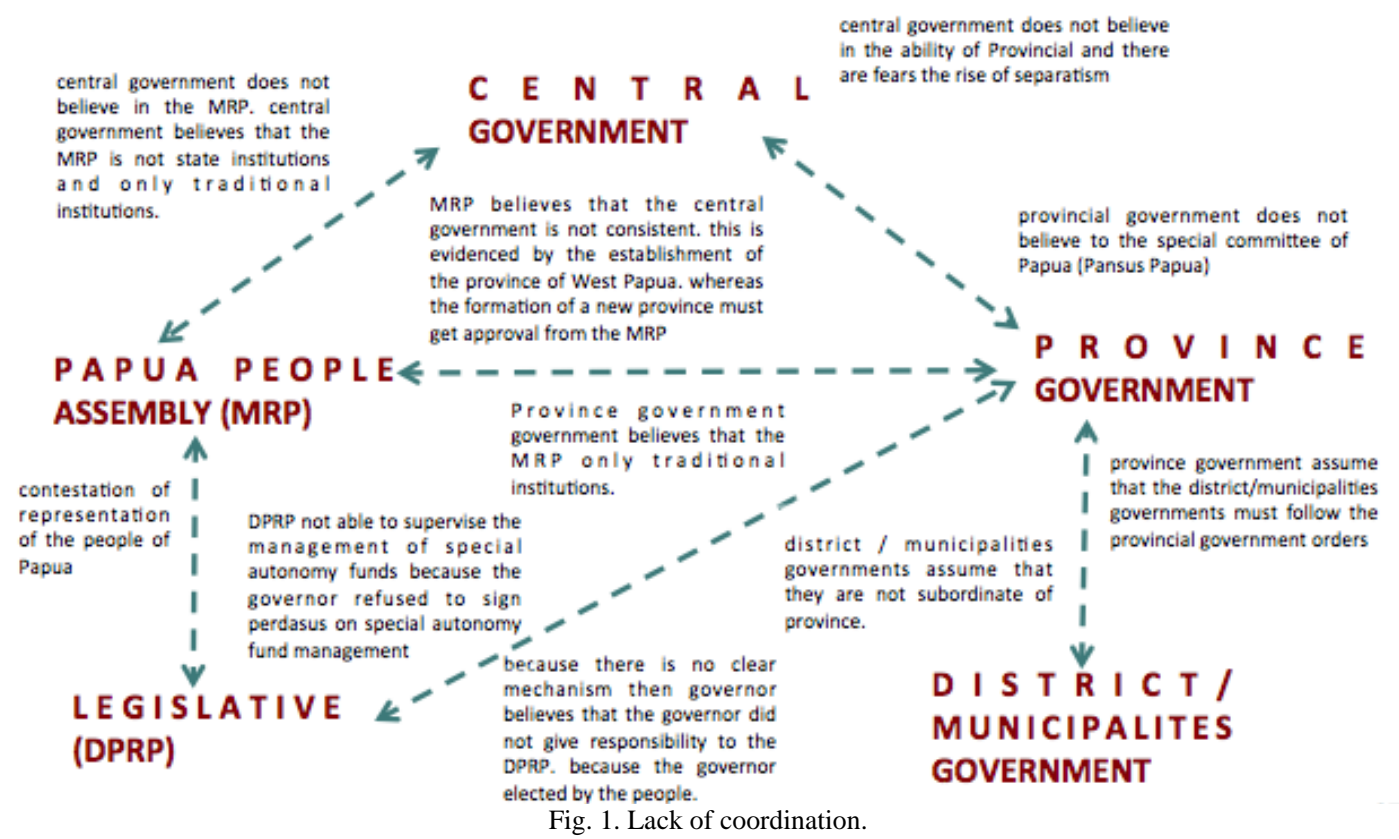

The seizure of authority, as well as throwing authority, happens concerned with the making of further implementation rules of Special Autonomy Law. On one hand, the central government blamed the provincial government for the absence of Perdasus and Perdasi in further governing autonomy. While, on the contrary, the provincial government also threw responsibility to the central government on central government's inability to produce a variety of government regulations as a follow-up of the Special Autonomy Law. In fact, this is the government regulation that will be the basis for the provincial government, DPRP, and MRP to generate a variety of Perdasus and Perdasi. Only three PP (government regulations) born by the central government related to the implementation of special autonomy in Papua. The first, PP No. 54 of 2004 on the Papuan People's Assembly. Second, PP No. 24 of 2007 on the province of West Irian into West Papua. Third, PP No. 19 of 2010 on Procedures for the Implementation of Duties and Powers and Financial Position as Deputy Governor to the Provincial Government. There are still many PP, which have not been made, such as PP on mining, forest management, and indigenous or customary rights. As for the Perdasus, from 18 Perdasus targeted, only 8 Perdasus generated [20]. There are still many Perdasus, which have not been made. For example Perdasus on procedures for the election of governor and deputy governor, the implementation of MRP obligations, and resource sharing between the provincial and District/Municipality.

Although the central government has not formally evaluated the implementation of the special autonomy Law in Papua, but some officials in Ministry of Home Affairs on several occasions said that the central government considers the application of special autonomy in Papua during the past decade have failed. There are some indications of that

assessment, namely autonomy fund governance, the effectiveness of representation in MRP and DPRP as well as capacity building bureaucrats in Papua.

In contrast, the provincial government in Papua also assumes that central government is very dominant in the process of expansion of West Papua Province and some areas of the District/Municipality. Though, this division does not always suit the needs, just get rid of the existing resources. Instead, the central government said that the division becomes very necessary in rural areas, which are geographically very difficult to reach. Splitting in this context is to improve the quality and quantity of public services in rural or mountainous areas.

In general, there are indications that central government limits the authority of provincial government in Papua on the basis of concerns about public demands for independence from Papuan. In other words, the central government is still reluctant to give full authority to the provincial government in Papua for reasons of disintegration. On the other hand, the provincial government and the institutions of government in Papua try to draw the authority, which is perceived to be theirs by threats of secession from Indonesia. The situation is certainly very unfortunate both, not only the central government does not have a good reason, but also because of independence issue became a political commodity in the process of bargaining for power.

\section{Institutional Conflict: DPRP vs. MRP}

Regarding function and status of MRP, although normatively been regulated about the positions, the duties and responsibilities, the rights and obligations of MRP, but until now the reality has not gone as planned. MRP membership consists of three components namely religion, customs, and women, merely positioned as traditional and 
cultural institutions that function over to give only cultural considerations and tend to just symbolic. The establishment of the West Papua MRP, which stand-alone separated to Papua MRP and MRP based on Law No. 35 of 2008 has not made this Papua special agency, runs faster and more active. If observed, Article 20 to Article 25 of the Special Autonomy Law, about the functions, duties and powers, rights and obligations, as well as the procedures for the election of MRP members, this institution then should be able to funnel the majority of Papuan to encourage the government and DPRD to work harder and prioritize the welfare of indigenous Papuan [21].

But it did not happen, due to various reasons MRP still more struggling at the completion of internal affairs of the institution itself. The political orientation of its members is so little, and some members involved in practical politics, not only lead to lower MRP institutional solidity but also to reduce the authority of MRP as a place of indigenous Papuan. As a result, decisions MRP no longer round but depend on the political tug. In fact, the formation of the MRP is motivated by several reasons. First, political rights of indigenous people and women tend to be neglected. Second, political representation of indigenous people and women in political institutions (political/legislative) not significant enough and tend to not be accommodated. Third, political aspirations of indigenous people and women tend to not be accommodated. Fourth, levels of political participation of indigenous society and women are relatively small. Fifth, commitment to respect the customs and culture, to empower women and strengthen religious harmony. Sixth, commitment to reconciliation among indigenous society and the population of Papua Province. Political rights of the indigenous community in Papua have not been adequately protected.

Also, the formation of the MRP took more than four years since the enactment of special autonomy Law. The new government issues the implementing regulation No. 54 of 2004 on the MRP, December 23, 2004. The proposal regarding the terms and amount as well as procedures for electing members of the MRP has been proposed to government by the Governor and DPRD as preparation materials of Government Regulation (PP) since July 14, 2002. If the government is consistent with the provisions of Article (2) of Autonomy Law, then the government should resolve the government regulation as referred no later than one month after the proposal is received [22].

\section{Symmetrical DeCENTRALIZATION IN NUSA TENGGARA BARAT}

To see as well as compare the asymmetrical and symmetrical decentralization, the author then describes the implementation of symmetrical decentralization in NTB (Southeast West Nusa). It is taken since NTB and Papua have the same level of GDP.

NTB get a very large budget transfers from the central government. This can be seen in the following Table IV:

Data above explained that the transfer of funds from the central government's 4 trillion rupiah. (US\$ 400 million). Now let us compare the local revenue of Nusa Tenggara Barat and Budget transfer from the central government (see Table V-Table VI).

\begin{tabular}{cccc}
\multicolumn{5}{c}{ TABLE IV: BLOCK GRANT, SPECIAL GRANT AND SPECIAL BUDGET IN NTB } \\
\hline Years & Block Grant (DAU) & $\begin{array}{c}\text { Special Grant } \\
\text { (DAK) }\end{array}$ & Total \\
\hline 2002 & $193,800,000,000.00$ & $85,000,000,000.00$ & $278,800,000,000.00$ \\
2003 & $223,950,000,000.00$ & $85,000,000,000.00$ & $308,950,000,000.00$ \\
2004 & $231,537,000,000.00$ & $85,000,000,000.00$ & $316,537,000,000.00$ \\
2005 & $249,890,000,000.00$ & $85,000,000,000.00$ & $334,890,000,000.00$ \\
2006 & $404,145,000,000.00$ & $85,000,000,000.00$ & $489,145,000,000.00$ \\
2007 & $447,658,000,000.00$ & $85,000,000,000.00$ & $532,658,000,000.00$ \\
2008 & $511,286,000,000.00$ & $37,215,000,000.00$ & $548,501,000,000.00$ \\
2009 & $608,612,000,000.00$ & $48,024,000,000.00$ & $656,636,000,000.00$ \\
2010 & $602,389,000,000$ & $48,024,000,000$ & $650,413,000,000.00$ \\
2011 & $646,671,000,000$ & $75,250,000,000$ & $721,921,000,000.00$ \\
\hline
\end{tabular}

Source: Ministry of Finance

TABLE V: THE COMPARISON BETWEEN LOCAL REVENUE AND BUDGET TRANSFER FROM CENTRAL GOVERNMENT

\begin{tabular}{rrr}
\multicolumn{3}{c}{ TRANSFER FROM CENTRAL GOVERNMENT } \\
\hline Years & Local Revenue (PAD) & $\begin{array}{r}\text { Budget Transfer from } \\
\text { Central Government }\end{array}$ \\
2002 & $8,224,900,000.00$ & $278,800,000,000.00$ \\
2003 & $11,464,600,000.00$ & $308,950,000,000.00$ \\
2005 & $14,079,200,000.00$ & $316,537,000,000.00$ \\
2006 & $15,343,500,000.00$ & $334,890,000,000.00$ \\
2007 & $23,780,500,000.00$ & $489,145,000,000.00$ \\
2008 & $31,161,600,000.00$ & $532,658,000,000.00$ \\
2009 & $34,974,800,000.00$ & $548,501,000,000.00$ \\
2010 & $46,821,000,000.00$ & $656,636,000,000.00$ \\
2011 & $52,918,200,000$ & $650,413,000,000.00$ \\
\hline Total & $70,988,900,000$ & $721,921,000,000.00$ \\
\hline Source: Ministry of Finance
\end{tabular}

TABLE VI: The PERCENTAge OF POOR PEOPLE IN NTB

\begin{tabular}{cc} 
TABLE VI: THE PERCENTAGE OF POOR PEOPLE IN NTB \\
\hline Years & Percentage of Poor People \\
\hline 2004 & 25 \\
2005 & 25 \\
2006 & 27 \\
2007 & 24 \\
2008 & 22 \\
2009 & 23 \\
2010 & 21 \\
\hline 2011 & 23 \\
\hline
\end{tabular}

Source: BPS

The data explained that total of local revenue of NTB province amounted 300 million rupiah (US\$ 30 million). Meanwhile, the transfer budget from the central government amounted 4 trillion rupiah (US\$ 400 million). This suggests that the NTB is highly dependent on budget transfers from the central government.

Large budget given by the central government, evidently did not give a very big change at NTB. It can be proved from the higher levels of poverty. The poverty level can be seen in the following table.

Symmetrical decentralization implementation in NTB did not provide a significant benefit. This is evidenced by the number of poor people has not decreased. NTB including the poorest provinces in Indonesia. Based on the implementation of asymmetrical decentralization in Papua and symmetrical decentralization in West Nusa Tenggara, which the authors found that decentralization is not a positive impact on improving the welfare. The authors propose a model of 
sequential asymmetric decentralization.

\section{Sequential Asymmetric Decentralization: New DESIGN}

Based on David Held theory, the fundamental problem in the state is how to build a good model or system that regulates social relations and the state to create stability in the state. Therefore, I assume that the implementation of decentralization in Indonesia is weak. This condition led to the study of sequential asymmetric decentralization. I argue that decentralization is not only asymmetrical decentralization but continue to the sequential decentralization. It means the decentralization in Indonesia is not enough just to be asymmetrical decentralization. I agree that decentralization must begin with the assumption that the regional pluralism has diversity. The implementation of decentralization in the region should be a level in the implementation of decentralization. Sequential asymmetric decentralization is a model that could answer problems caused by decentralized symmetric or asymmetric weakness that occurs at this time. In other words, as long as it uses symmetric decentralization for uniformity principle with the assumption that all the provinces, regencies /cities have the same ability. In reality, most of the provinces, regencies/cities have differences. Symmetric is considered weak because it uses the principle of uniformity, which raises asymmetric models. Many studies have attempted to offer on the terms asymmetric with distinction shared by many regions in Indonesia. Unfortunately, asymmetric decentralization focuses only on the level of the formation of the new region. In fact, asymmetrical decentralization in Indonesia such as Papua is not good implementation because poverty still increases in Papua.

Sequential decentralization version then present to answer the question of asymmetric and symmetric. Falleti assumes that decentralization should rise started from administrative, fiscal and political. However, the problem is the use of thought Falleti into decentralization in Indonesia has not been able to answer the problem. That's because the three things it is not sufficient to support a portrait of decentralization in Indonesia.

Addressing to the number of the references, the choice of a sequential asymmetrical decentralized development model based on the diversity of the region. Each area is treated differently because it assumes the existence of extreme pluralism that the central government must respond. The problems in the implementation of decentralization in Indonesia should be taken seriously. Model of decentralization in Indonesia is very prone to conflict. Therefore, I offer the concept of decentralization called sequential asymmetric decentralization. The basic idea of sequential asymmetric decentralization began in Indonesia under which decentralization should start from asymmetric. Every region in Indonesia has the diversity and capabilities that cannot be equated. However, the central government assumed that all provinces in Indonesia have the ability, the same circumstances. Based on government regulations No. $38 / 2007$ explained that provinces submitted 31 types of affairs in the same amount and the same authority as well. I think it cannot be equated. That's because not all the provinces are the same so every province should be given different affair or proportion depends on the ability of the region.

Based on this condition, I propose sequential asymmetric decentralization model to improve the decentralization in Indonesia. I argue that there must be a ranking system applied in decentralization. Then, periodically or once in five years, all the regions are evaluated by the central government to assess the results of the implementation of decentralization. Through this ranking system, the central government will give a reward for the best region. I categorize in 5 levels of decentralization achievement (will be explained below in subchapter). For example, Jakarta in the first five year is in category 5. If Jakarta in the next five years decreases the quality of the decentralized, Jakarta position will go down grade into level 3. The impact of a downgrade is that the local authority will be reduced by the central government, on the other hand, for the upgrade level would be rewarded a larger authorities.

\section{CONCLUSION}

Symmetrical and asymmetrical implementations of decentralization in Indonesia have failed. This is evidenced by the implementation of decentralization in Papua and NTB. Both provinces are in the position of the poorest in Indonesia. Therefore, Indonesia needs a new model of decentralization called sequential asymmetrical decentralization. This decentralization is a gradual decentralization model and did not put the province in the same position. The position will be assessed based on merit and ability of local budgets. If the area is only able to build a small house then not be forced to build a skyscraper.

\section{ACKNOWLEDGMENT}

The author would like to extend special thanks to Prof. Yuzuru Shimada from Graduate School of International Development (GSID), Nagoya University- Japan, Dr. Zainal Arifin Muchtar (UGM), Dr. Wijayanto Samirin, Dr. Mardianto (LIPI), Department of Political Science (USU-Medan), Indonesian Government Scholarship (DIKTI) and all participant.

\section{REFERENCES}

[1] N. Robert, A Community and Power, Formerly the Quest For Community, London: Oxford University Press, 1968, p. 162

[2] H. David, Political Theory and the Modern State, Cambridge: Polity Press, 1984.

[3] S. T. Ahmad, To Wards Good Governance, UK: Oxford University Press, 2001, p. 9.

[4] N. Devas, "Indonesia: What do we mean by decentralization," Public Administration and Journal, vol.7,1997

[5] D. Rondinelli, "What is decentralization?" World Bank, Decentralization Briefing Notes, 1999

[6] The World Bank, Independent Evaluation Group, Decentralization in Client Countries-An Evaluation of World Bank Support, pp. 10-11.

[7] J. Litvack and R. Bird, "Rethingking decentralization in developing cuntries," Washington DC, p. 2.

[8] M. Turner and D. Hulme, "Governance, administration and development: Making the state work," London: Macmillan Press Ltd., p. $152,1997$.

[9] P. Smoke, "Decentralization and human rights," International Council on Human Rights Policy, p. 8.

[10] R. C. Crook and J. Manor, Democracy and Decentralization in South Asia and West Africa, p. 14 
[11] R. S. Emmette, Democracy in the Administrative State, p. 21

[12] Kauzya, "Decentralization: prospect for peace, democracy and developmen," UNDP Report, 2001.

[13] J. Mbeya, "Unity and diversity in symmetrical decentralization," Working paper, Institute of Federalism, 2012.

[14] A. A. Dwipayana, "Mengelola desentralisasi di Indonesia," $U G M$, Yogyakarta, 2011

[15] R. E. Jaweng, "Kritik terhadap desentralisasi di Indonesia," CSIS Journal, vol. 40, no. 2, June 2011

[16] T. G. Faletti, "A sequential theory of decentralization and its effects on the intergovernmental balance of power: Latin American cases in comparative perspective," Working paper, p. 3.

[17] Pratikno, "Asymmetrical decentralization in Indonesia: Practical and future," Faculty of Social and Political Science., Yogyakarta, 2010, pp 15-17.

[18] J. R. Kaho, Analisis Hubungan Pemerintah Pusat dan Daerah di Indonesia, p.105

[19] M. S. Widjojo, Komunikasi Konstruktif dan Road Map Papua, Majalah Tempo, 2010
[20] Y. Sugandi, Analisis Konflik dan Rekomendasi Kebijakan Papua. 2008, p. 3 .

[21] E. Aspinall and G. Fealy, Local Power and Politics in Indonesia, p. 201

[22] A. Djojosoekarto, Kinerja Otonomi Khusus Papua, 2008, pp. 33-38.

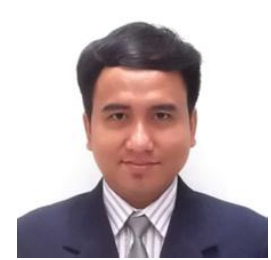

Indra Kesuma Nasution was born in Indonesia. He completed his BA and master's degree in Gadjah Mada University, Indonesia. Now, $\mathrm{He}$ is a $\mathrm{Ph} . \mathrm{D}$ student in Graduate School of International Development, Nagoya University, Japan. He is a lecturer at Faculty of Social and Political Science, Universitas Sumatera Utara, Indonesia. His research interests in decentralization and local politics in 